\title{
YOUR NEW GIRLFRIEND
}

SOPHIE MIHAILIDIS

Young girl, brushing pink dust

Over her cheekbones

Under bathroom lights, where I once stood,

Redressing at your request

Nervous and bothered, she sweetly

Enters the room holding your hand

Wearing a fake smile

Gritting her teeth at the mention of me

Immaturity gets the best of her

Red-faced, she is forced to

Listen to our stories

From people who used to know us

Ripping you apart with her words

In the car on the way home,

Every shred of your past concealed

New girlfriend

Don't forget who you are 